DOI https://doi.org/10.18551/rjoas.2017-10.37

\title{
SWEET CORN FARMING: THE EFFECT OF PRODUCTION FACTOR, EFFICIENCY AND RETURN TO SCALE
}

\author{
Dwijatenaya Ida Bagus Made Agung \\ Agribusiness Study Program, Faculty of Agriculture, University of Kutai Kartanegara, \\ Indonesia \\ E-mail: info@unikarta.ac.id
}

\begin{abstract}
This research aims to determine the effect of production factors on the sweet corn production, the efficiency of sweet corn farming, and the return to scale of sweet corn production. The sampling technique was taken by proportionate stratified random sampling method with the sample number of 57 people while the analyzer used was the program of Frointer 4.1c. The results show that the production factors of the land farm, seed, and fertilizer have a positive and significant effect on sweet corn production. On the other hand, labor production factors have a positive but not significant effect on sweet corn production. It also found that technical efficiency, price efficiency, and economic efficiency of sweet corn farming in Muara Wis Sub-district of Kutai Kartanegara Regency are not efficient yet. The return to scale of sweet corn yield has an increasing return to scale condition.
\end{abstract}

\section{KEY WORDS}

Sweet corn, farming, production factor, efficiency.

The grand strategy of Kutai Kartanegara Regency development in East Kalimantan, Indonesia puts agriculture as the main sector to be developed. This is demonstrated by the $4^{\text {th }}$ point of Kutai regency development mission in 2016-2021 to improve farm management. Besides rice as the main commodity, Kutai also develops non-rice food sources like corn.

The corn production in Kutai has fluctuated from 2011 to 2015 as presented in Table 1 below. The fluctuating production was caused by the changing size of the land use. In addition to that, corn farming has not been well managed. Various factors causing the underdevelopment of non-rice food products handling such as corn in Kutai are that the product market has not formed yet, limited post-food handlers and that the production has not developed properly. Corn production is determined by the factors of production. The production factors are the land area, labor, seeds, fertilizers, insecticides, and so forth. An efficient production process requires a combination of the optimal use of production factors and supported by technological master by farmers.

Table 1 - Area and Production if Corn in Kutai Kartanegara, 2015

\begin{tabular}{cccc}
\hline No. & Year & Area $($ ha) & Production (Tons) \\
\hline 1. & 2011 & 630 & 2015 \\
2. & 2012 & 581 & 1881 \\
3. & 2013 & 413 & 1342 \\
4. & 2014 & 249 & 834 \\
5. & 2015 & 420 & 1576 \\
\hline
\end{tabular}

Source: BPS of Kutai Kartenagara, 2016.

The fact that corn production has not been well developed in Kutai Kartanegara is inseparable from the people who still consider rice as their main food. The existence of government policies to improve the non-rice food production provide an opportunity for areas which have potential to develop corn production. Corn production is determined by various factors. Soekartawi in Risandewi (2013) explained that the factors affecting agricultural production are biological factors and socioeconomic factors. 
Production is defined as the use or utilization of resources that transform a commodity into other commodities which are completely different (Miller and Meiners, 1994:249). In brief, production is a process of transforming inputs into outputs. He also said that the relationship between the physical output and the physical input is referred as a production function. The production function determines the maximum output that can be produced from a certain number of inputs, in a state of technical expertise and specific knowledge (Samuelson dan Nordhaus, 2003:125). Experts give different symbols in defining the production function into a mathematical equation as Doll and Orazem (19, 84: 21); Miller and Meiners (1994: 261); and Nicholson (2002: 159) have proved. It is known that all of those equations give the same meaning. In general, the function of production is written as follows.

$$
Y=f\left(X_{1}, X_{2}, X_{3}, \ldots, X_{N}\right)
$$

Where: $Y$ is the output; $X_{1 \ldots . . N}$ is the input.

Experts in the study of the production function, including the production function in the agricultural sector, are commonly used the equation of Cobb-Douglas production function. The formulation is presented in this following section (Miller and Meiners, 1994:286; and Gujarati, 2007:213).

$$
Y=A X^{B}
$$

Furtherly, it is explained that the Cobb-Douglas function is a non-linear function to be linear. Therefore, the function is transformed into a form of natural logarithm equation.

$$
\operatorname{Ln} Y=\ln A+B \ln X
$$

Where: $A$ is the intercept; $Y$ is the output; $X$ is the input; $B$ is the regression coefficient.

Various studies on agricultural sector which examine the influence of production factors have been carried out by using the Cobb-Douglas model approach. Khakim et al., (2013) found that land, labor, fertilizer, and seed have a significant effect on rice production. Danilwan (2010) has proved that the influence of production factors (capital and labor) is significant to production (industrial output). The results from Darwanto (2010) showed that the factors of production that significantly affect the production are land area and seed, while the non-significant factors are pesticides, fertilizer, and labor. The research of Haryono et al., (2015) said that the factors of production have a simultaneous and significant effect on production. Some other studies related to the influence of production factors have been done by Gunes (2007); Simorangkir et al., (2014); Effendy and Antara (2015); and Dwijatenaya (2016).

Besides the Cobb-Douglas production function which is the physical connection between the production factors to production, then to analyze the efficiency of the production process, a stochastic production frontier Cobb-Douglas is used. An optimization of production factors aims to achieve maximum profits in every business including sweet corn farming by allocating the production factors efficiently. According to Soekartawi (2001:49), the notion of efficiency is classified into three types, namely (1) the technical efficiency, (2) allocative efficiency (price), and economic efficiency. Moreover, it can be seen in CobbDouglas function that the regression coefficient describes the elasticity of production. Thus, the marginal product value (MPV) of X production factors is formulated as follows.

$$
\mathrm{MPV}=(b \cdot Y \cdot \mathrm{Py}) / X
$$

Where: $\mathrm{b}$ is the elasticity of production; $\mathrm{Y}$ is the production; $\mathrm{Py}$ is the price of production; $\mathrm{X}$ is the $\mathrm{X}$ production factor(s).

The condition of price efficiency requires MPV to be equal to the price of production factor. However, this condition is difficult to achieve for many reasons such as farmers' 
limited knowledge, the difficulty to obtain production factors in the right amount, time management, and so on. The formulations of those conditions are:

\author{
$(b . Y . P y) /(X . P x)=1$; efficient condition \\ $(b . Y . P y) /(X . P x)>1$; inefficient $\mathrm{X}$ production factors \\ $($ b.Y.Py $) /(X . P x)<1$; the use of $X$ production factors is considered inefficient
}

To measure price efficiency and economic efficiency, it requires a technical efficiency. According to Miller and Meiners (1994: 260), technical efficiency requires or entails a production process that can utilize fewer inputs in order to produce output in the same amount. Battese and Coelli in Sukiyono (2004) defines technical efficiency as the ratio between the farming production and output (production) of the frontier production function. By that, the value of technical efficiency can be determined with the help of Frontier Software $4.1 \mathrm{c}$ Version. The indicators are consisted of (1) if the value of technical efficiency is equal to one, the use of production factors has been technically efficient and (2) if the value of technical efficiency of less than one, the use of production factors is not yet technically efficient.

The concept of economic efficiency embodied the idea that the best of this is the most cost-effective (Miller and Meiners, 1994:261). Economic efficiency is the product of technical efficiency and price efficiency of all input factors. Economic efficiency is defined as follows (Soekartawi, 2001:49).

$$
E E=E T . E H
$$

Where: $E E=$ Economic efficiency; TE = Technical Efficiency; PE = Price Efficiency.

The indicators of economic efficiency value are: $E E<1$ means inefficient so that the use of production factors should be reduced; $E E=1$ means efficient so that the combination of the use of production factors is appropriate; EE $>1$ means not efficient so that the use of production factors should be increased.

Ismayani (2013) in her research used the approach of Cobb-Douglas production function through regression analysis that is related to efficiency. She found that production factors of land and labor are still inefficient. Suprapti et al., (2014) also analyzed the efficiency of corn production with the approach of stochastic production frontier CobbDouglas. It is obtained that the level of economic efficiency and technical efficiency are inefficient while the allocative efficiency is already efficient. Some studies related to farm efficiency are carried out by Danilwan (2010); Sarinah (2010); Dewi et al,. (2012) and Simorangkir et al., (2014).

To determine whether a business including corn farming is in the business scale of constant, increasing, or decreasing, it can be analyzed with a return to scale model. Nicholson (2002: 169) defined the return to scale as a situation in which the output is increased in response to a proportional increase of all inputs. There are three possibilities in return to scale, namely (1) increasing return to scale, when each additional unit of input generated more additional output compared to the previous input, (2) constant return to scale, when additional unit of input produced the same output like the previous unit, and (3) decreasing return to scale, when each additional unit of input generated less additional output compared to the previous input. Research related to the return of scale conducted by Darwanto (2010) found that the return to scale of rice farming is in a state of increasing the return to scale. Khakim et al., (2013) also discovered that the return of scale of rice farming in Central Java is in a state of increasing the return to scale. Rahadi and Aswitari (2015) have examined that the economic scale of leather bag handicraft industry in Denpasar is in a state of increasing the return to scale. Moreover, Dwijatenaya (2016) found that the return to scale of barley is in a state of increasing the return to scale.

Besides the similarity with previous research which is examining corn farming, this research also has several differences. This research is focused on sweet corn farming seen from the aspects which influence the production factor usage, farming efficiency, and the 
return to scale with a locus in Muara Wis, Kutai Kartanegara of East Kalimantan. Furthermore, more detailed equations and differences are described in the discussion. The use of production factors such as labor, land area, seed, and fertilizer affect the production of sweet corn. The combination of these production factors reflected the condition of the farming whether it is inefficient, not yet efficient, or already efficient. Similarly, the combination of the use of production factors will reveal whether the farm is in a state of decreasing return to scale, constant return to scale, or increasing the return to scale. The research objective is to determine the influence of production factors to the production of sweet corn as well as to know the sweet corn farming efficiency and return to scale.

\section{METHODS OF RESEARCH}

This research used a quantitative data. The data were described in the form of numbers obtained from the results of research including; corn production, land area, the use of seeds, the use of labor, the use of fertilizers, corn farming absorption, the cost of land, the cost of seeds, the cost of labor, and the cost of fertilizer. The sources of data used in this study were primary and secondary data. Primary data were collected and obtained directly from the source which in this case was from the farmers (respondents). Furthermore, secondary data were collected from the Central Bureau of Statistics of Kutai Kartanegara such as the area and the corn production in Kutai Kartanegara Regency. Data in scientific research are intended to obtain a relevant, accurate, and reliable data. Therefore, a good and suitable data collection method is required. In this research, data collection technique was carried out by questionnaires, structured interviews, and observation (Sugiyono, 2012:187-198).

The framework of this research was done by using quantitative research design and survey method. The study population was 131 farmers. These number of samples were taken by using Slovin formula (Sedarmayanti and Hidayat, 2002: 143) at the level of sampling error (e) by 10 percent in order to obtain 57 respondents. A sampling of respondents was reached by Proportionate Stratified Random Sampling method.

To answer research objectives, the research used analytical techniques of stochastic production frontier Cobb-Douglas function model with the parameter of Maximum Likelihood Estimated (MLE). The data were processed with the help of a computer program called Frontier 4.1c. The stochastic frontier production function used for sweetcorn farming is assumed to have a Cobb-Douglas form. For the purpose of function analysis, it is transformed into a linear form of the natural logarithm. The equation is formulated as follows (Coelli et al., in Darwanto, 2010).

$$
\operatorname{Ln} Y=b_{0}+b_{1} \ln X_{1}+b_{2} \ln X_{2}+b_{3} \ln X_{3}+b_{4} \ln X_{4}+V_{i}-U_{i}
$$

Where: $b_{0}$ is intercept; $Y$ is the result of sweet corn production $(\mathrm{kg}) ; X_{1}$ is the land area (ha); $X_{2}$ is the seed $(\mathrm{kg}) ; X_{3}$ is the labor $(\mathrm{HOK}) ; X_{4}$ is the fertilizer $(\mathrm{kg}) ; b_{1} \ldots b_{4}$ is the regression coefficient; $V_{i}$ is the random error of model; $U_{i}$ is the random variable that presenting the inefficiency technique of the i-th sample.

To know the influence significance of production factors on sweet corn production, $t-$ ratio is consulted to t-table. If the t-ratio is greater than the t-table, it can be said that the production factors have a significant influence on production. If t-ratio is less than t-table, then, the influence of production factor is not significant.

With the help of Frontier Software 4.1c, the value of technical efficiency (TE) can be determined by two assessments, such as; (a) If the value of technical efficiency is equal to one $(=1)$, then the use of production factors is technically efficient, and (b) If the value of the technical efficiency is less than one $(<1)$, then the use of production factors is inefficient. Furthermore, to calculate the efficiency of price (PE), the formulation can be seen below.

$$
\mathrm{PE}=(\mathrm{MPV} 1+\mathrm{MPV} 2+\mathrm{MPV} 3+\mathrm{MPV} 4) / 4
$$


The condition of price efficiency requires MPV to be equal to the price of production factors. However, this condition is difficult to achieve. The condition can be seen as this following formulation.

$(b . Y . P y) /(X . P x)=1 ;$ efficient

$($ b. $Y . P y) /(X . P x)>1$; the use of $\mathrm{X}$ production factor has not been efficient

$(b . Y . P y) /(X . P x)<1$; the use of production factors is considered inefficient

After the technical efficiency (TE) and price efficiency (PE) is known, then, the economic efficiency can be obtained by formula (6) below.

$$
E E=T E / P E
$$

The economic efficiency indicator is described as follows: EE $<1$ means inefficient so that the use of production factors should be reduced; $E E=1$ means efficient so that the combination of the use of production factors is appropriate; EE > 1 means not efficient so that the use of production factors should be increased.

$b_{1}, b_{2}, b_{3}$, and $b_{4}$ on the Cobb-Douglas function show the elasticity of $X$ to $Y$, and the amount of elasticity means a return to scale. If $b_{1}+b_{2}+b_{3}+b_{4}=1$, the production function will generate a state of constant return to scale. This means that the increase in the input will be followed by the increase in the proportion of sweet corn production. If $b_{1}+b_{2}+b_{3}+b_{4}<1$, the production function will show the state of decreasing return to scale which means that the increasing percentage of the production of sweet corn is smaller than the increasing percentage in the input. Lastly, if $b_{1}+b_{2}+b_{3}+b_{4}>1$, the production function will generate the state of increasing the return to scale. This means that the increasing percentage of sweet corn production (output) is greater than the increasing percentage of the input.

\section{RESULTS AND DISCUSSION}

The Effect of Production Factors on Sweet Corn Production. Sweet corn production is determined by several factors. In this analysis, the production factors which influence the production of sweet corn farming are; labor, land, and seed. To determine whether the factors significantly influence the production of sweet corn or not, the analysis of Stochastic Frontier production function is used. With the help of computer software of Frontier 4.1c, the results are summarized as presented in Table 2 below.

Table 2 - Estimation Results of Stochastic Frontier Function on Sweet Corn, 2017

\begin{tabular}{lllll}
\hline Variables & Coefficient & Standard Error & t-ratio & Keputusan \\
\hline Intercept & 0,029 & 0,151 & 0,193 & \\
Labor & 0,025 & 0.052 & 0,047 & n-Sig \\
Land area & 0,311 & 0,104 & 3,001 & Sig \\
Seed & 0,689 & 0,088 & 7,847 & Sig \\
Fertilizer & 0,078 & 0,013 & 6,065 & Sig \\
Sigma-squared & 0,326 & 0,052 & & \\
Gamma & 0,999 & 0,0004 & & \\
Log Likelihood & $-10,921$ & & & \\
LR & 11,567 & & & \\
Mean Tech. Eff. & 0,6579 & & & \\
\hline
\end{tabular}

Note: $t$-Table $(\alpha=1 \%)=2,423 ; t$-Table $(\alpha=5 \%)=2,021 ; t$ Table $(\alpha=10 \%)=1,303$.

Based on the estimation of stochastic frontier production function model, the meaning of each sweet corn production factors is described as follows. The value of labor variable is positive. However, the effect of labor on sweet corn production is not significant at all levels $(\alpha=1 \%, \alpha=5 \%$, and $\alpha=10 \%)$. This is because farmers prefer to recruit family members in the process of sweet corn production in Muara Wis, Kutai Kartanegara, East Kalimantan. The result of the research shows that the influence of labor is not significant to production. This is 
in line with the findings of Darwanto (2010) and Dwijatenaya (2016). The coefficient of production factors of land area by 0,311 implies that the addition of land area by one percent (ceteris paribus) will be able to increase the production of sweet corn by 0,311 percent. By that, it can be said that the land area has the positive and significant effect on the production of sweet corn. The significant and positive effect shows that the land area will increase the production of sweet corn. These findings are in line with the research results of Gunes (2007); Khakim et al., (2013); and Haryono et al., (2015).

The coefficient value of seed production factor by 0,689 implies that the addition of seeds by one percent (ceteris paribus) will be able to increase the production of sweet corn by 0,689 percent. The statistics show that the effect of seed on sweet corn production is positive and significant. The more the number of seeds used, the greater the production of sweet corn. The findings of this study are in line with the research findings of Darwanto (2010); Khakim et al., (2013); and Simorangkir et al., (2014). Moreover, fertilizer also has a positive and significant effect on sweet corn production in Muara Wis, Kutai Kartanegara. If the application of fertilizer is increased, it will increase the production of sweet corn. The coefficient value of fertilizer by 0,078 implies that the addition of fertilizer by one percent (ceteris paribus) will increase the production of sweet corn by 0,078 percent. The findings of this study are in line with the findings of Khakim et al., (2013); Haryono et al., (2015); and Effendy and Antara (2015).

Technical Efficiency, Price Efficiency and Economic Efficiency. In order to gain profits, farmers must be able to use the production factors efficiently. However, the increased use of production factors not necessarily implies that the farm has been efficient. Based on the calculation of technical efficiency through the help of a computer program called Frontier 4.1c, the value of technical efficiency is 0,658 . The value of technical efficiency by 0,658 means that the average productivity of sweet corn farming is 65,8 percent of the maximum production. If the value of technical efficiency is less than one $(0.658<1)$, this indicates that the use of production factors in this corn farming is not efficient. The results of this study support the findings of Suprapti et al., (2014) and Simorangkir et al., (2014).

The price efficiency describes a condition when the marginal product value (MPV) is equal to the price of production. Based on the calculation results as shown in Table 4, the sweet corn farming is still inefficient $(10,247>1)$.

Table 3 - Summary of MPV Calculation on Sweet Corn Farming, 2017

\begin{tabular}{llll}
\hline Variable & $\mathrm{b}$ & Average Revenue and Cost (IDR) & MPV \\
\hline Production & & $26,684,309,74$ & 27,663 \\
Land area & 0,311 & 300,000 & 4,970 \\
Seed & 0,689 & $3,699,245,94$ & 0,189 \\
Labor & 0,025 & $3,522,331,79$ & 8,164 \\
Fertilizer & 0,078 & $254,930,39$ & 40.987 \\
\hline \multicolumn{2}{r}{} & & \\
\hline
\end{tabular}

Table 4 - The value of Technical Efficiency, Price Efficiency, Economic Efficiency and Results Scale, 2017

\begin{tabular}{|c|c|c|c|c|}
\hline Variable & Coefficient & MPV & & Efficiency \\
\hline Land area & 0,311 & 27,663 & $\mathrm{EH}$ & $=10,247$ \\
\hline Seed & 0,689 & 4,970 & $\mathrm{ET}$ & $=0,658$ \\
\hline Labor & 0,025 & 0,190 & EE & $=6,743$ \\
\hline Fertilizer & 0,078 & 8,164 & & \\
\hline Total & 1,103 & 40,987 & & \\
\hline
\end{tabular}

The production factors that have not been efficient in sweet corn farming consist of the use of land area, the use of seeds, and the use of fertilizers. Meanwhile, the inefficient production factor is only the use of labor. The use of production factors in Muara Wis, Kutai Kartanegara area can be expanded. This is because the average land area owned by farmers is 0,3 hectares while there's still spacious land in Muara Wis. However, farmers cannot increase the use of high-quality seed and balanced fertilizer because the region is 
located in a rural area so that there are many obstacles to be faced. In correlation to labor, the inefficient use of labor happens because the majority of the workers are from the family itself so that they do not have to concern about the high cost of labor. The results show that sweet corn farming has not been effective as it is in line with the findings of Ismayani (2013); Suprapti et al., (2014) and Simorangkir et al., (2014).

After technical efficiency (TE) and allocative efficiency or price efficiency (PE) are known, the economic efficiency can be calculated afterward. The concept of economic efficiency embodied the idea that the best of this is the most cost-effective (Miller and Meiners, 1994). Economic efficiency is the multiply result of technical efficiency and price efficiency of all input factors. According to Wadud in Suprapti et al., (2014), price efficiency and technical efficiency can provide an overview of relative success on farming through four ways: (1) technically and allocatively efficient farming, (2) technically efficient farming but allocatively inefficient, (3) technically inefficient farming but allocatively efficient, and (4) technically and allocatively inefficient farming. Based on the calculation, it is obtained that the value of economic efficiency is 6,73 (Table 3 ). The value of economic efficiency by 6,73 $(E E=6,73)$ implies that the use of production factors in sweet corn farming is not efficient economically $(6,73>1)$. This means that the addition of production factors is needed as for an instance by increasing the use of land area. These findings are in accordance with the research of Suprapti et al., (2014) and Simorangkir et al., (2014).

Return to Scale. Based on the calculations, the return to scale of sweet corn farming is amounted up to 1,103 as presented in Table 3. This shows that the sweet corn farming in Muara Wis, Kutai Kartanegara is in a condition of increasing the return to scale. This means if there is an addition of production factor by one percent, it will increase the production of sweet corn (output) up to 1,281 percent. It can be seen that the production (output) is more than one percent, meaning that the condition of sweet corn farming is good to be developed or continued. The results of this study are in line with the results of Darwanto (2010); Khakim et al., (2013); Rahadi and Aswitari (2015); and Dwijatenaya (2016).

\section{CONCLUSION}

The results of this study consist of the production factors (land area, seeds, and fertilizers) which have a significant and positive effect on the production of sweet corn. While on the other hand, the production factor of labor has a positive but not significant effect on sweet corn production. By that, technical efficiency, price efficiency, and economic efficiency of sweet corn farming in Muara Wis, Kutai Kartanegara are not efficient yet. It also noted that the return to scale of sweet corn production is not efficient yet. This shows that the return to scale of sweet corn farming in Muara Wis, Kutai Kartanegara is in a state of increasing return to scale.

\section{REFERENCES}

1. Badan Pusat Statistik Kabupaten Kutai Kartanegara. (2016). Kabupaten kutai kartanegara dalam angka 2016. Tenggarong: Badan Pusat Statistik Kabupaten Kutai Kartanegara.

2. Danilwan, Yuris. (2010). Analisis Industri Rotan Jawa Barat dengan Model Constan Elasticity of Substitution (CES). Trikonomika, 9(2), hal 113-123.

3. Darwanto. (2010). Analisis Efisiensi Usahatani Padi Di Jawa Tengah (Penerapan Analisis Frontier). Jurnal Organisasi dan Manajemen, 6 (1), hal 46-57.

4. Dewi, I Gusti Ayu Chintya, I Ketut Suamba, dan I G.A.A. Ambarawati. (2012). Analisis Efisiensi Usahatani Padi Sawah (Studi Kasus di Subak Pacung Babakan Kecamatan Mengwi Kabupaten Badung. E-Journal Agribisnis dan Agrowisata, 1(1).

5. Doll, John P. Dan Frank Orazem. (1984). Production economics theory with application. Second Edition. United State of America: John Wiley \& Sons.Inc. 
6. Dwijatenaya, Ida Bagus Made Agung. (2016). Analisis Usahatani Jelai (Coix lacryma-Jobi I.) Sebagai Sumber Pangan Alternatif di Kabupaten Kutai Kartanegara. Kalimantan timur. Jurnal Gerbang Etam,10(2), hal 46-53.

7. Eftendy dan Made Antara. (2015). Effect of Input Production Against Quality of Cocoa Beans. American Journal of Aplied Sciences, 12(10). hal 709.713.

8. Gujarati, Damodar N. (1992). Dasar-dasar ekonometrika. Jilid 1. Terjemahan oleh Julius A. Mulyadi. 2007. Jakarta: Penerbit Erlangga.

9. Gunes, Erdogan. (2007). The Econometric Analysis of Tomato Production with Contracting in Turkey. Journal of Applied Science, 7(14): pp 1981-1984.

10. Haryono, Syukur Umar, DESS dan Erniwati. (2015). Analisis Produksi dan Pendapatan Pada Izin Usaha Industri Primer Hasil Hutan Kayu (IUIPHHK) Di Kota Palu Studi Kasus Pada PT. Tatehe Nusa Jaya. E-Jurnal Mitra Sains, 3(2), hal 72-80.

11. Ismayani. (2013). Efisiensi Penggunaan Faktor Produksi Usahatani Kunyit di Kecamatan Lampanah Lengah Kabupaten Aceh Besar. Agrisep, 14(2).

12. Khakim, Ludfil, Dewi Astuti, dan Aniya Widiyani. (2013). Pengaruh Luas Lahan, Tenaga Kerja, Penggunaan Benih, Dan Pupuk Terhadap Produksi Padi Di Jawa Tengah. Mediagro, 9 (1), hal 71-79.

13. Miller, Roger Leroy dan Roger E. Meiners. (1986). Teori ekonomi mikro intermediate. Terjemahan oleh Haris Munandar. (1994). Jakarta: PT. RajaGrafindo Persada.

14. Nicholson, Walter. (2000). Mikroekonomi intermediate dan aplikasinya. Edisi Ke Delapan. Terjemahan oleh IGN Bayu Mahendra dan Abdul Azis. (2002). Jakarta: Erlangga.

15. Rahadi, I Gusti Agung Bagus Indra dan Luh Putu Aswitari. (2015). Analisis Skala Ekonomi Pada Industri Kerajinan Tas Kulit di Kota denpasar. E-Jurnal EP Unud, 4(12).

16. Risandewi, Tri. (2013). Analisis Efisiensi Produksi Kopi Robusta di Kabupeten Temanggung (Studi Kasus di Kecamatan Candiroto). Jurnal Litbang Provinsi Jawa Tengah, 11(88).

17. Samuelson, Paul A. dan William D. Nordhaus. (2001). Ilmu mikroekonomi. Edisi tujuh belas. Terjemahan oleh Nur Rosyidah, Anna Elly dan Bosco Carvallo, (2003). Jakarta: PT. Media Global Edukasi.

18. Sarinah. (2010). Efisiensi Penggunaan Faktor Produksi Pada Usahatani Padi Sawah di Kabupaten Konawe. Warta-Wiptek, 18(02).

19. Simorangkir, Ronald, Max Nur Alam dan Abdul Muis. (2015). Analisis Efisiensi Penggunaan Input Produksi Usahatani Jagung Manis di Desa Maku Kecamatan Dolo Kabupaten Sigi. J. Agroland, 21(1), hal 37-44.

20. Soekartawi. (2001). Agribisnis teori dan aplikasinya. Jakarta: PT RajaGrafindo Persada.

21. Sugiyono. (2012). Metode penelitian kombinasi (mixed methods). Bandung: Alfabeta, CV.

22. Sukiyono. (2004). Analisa Fungsi Produksi dan Efisiensi Teknik: Aplikasi Fungsi Produkso Frontier Pada Usahatani Cabe Di Kecamatan Selepu Rejang, Kabupaten Rejang Lebong. Jurnal IImu IImu Pertanian Indonesia, 6(2), hal 104-110.

23. Suprapti, Isdiana, Dwidjono Hadi Darwanto, Jangkung Handoyo Mulyo, dan Lestari Rahayu Waluyati. (2014). Efisiensi Produksi Petani Jagung Madura Dalam Mempertahankan Keberadaan Jagung Lokal. Agriekonomika, 3(1). 